\title{
HYDROGEOCHEMICAL AND BIOPHYSICAL CHARACTERIZATION OF GROUNDWATER IN EASTERN NIGERIA: A CASE STUDY OF ONITSHA AND ENVIRONS
}

\author{
M. I. Isikhueme ${ }^{1,}{ }^{*}$ and 0. M. Omorogieva ${ }^{2}$ \\ 1,2, DePartment of Geology, University of Benin, Benin City, Edo State. NiGERIA \\ E-mail addresses. ${ }^{1}$ sesbet@gmail.com, 2 marvellousdegrea@yahoo.com
}

\begin{abstract}
Hydro-geological studies revealed that Onitsha and environs tapped their groundwater from the middle aquifer ( $>$ $40 \mathrm{~m}<90 \mathrm{~m}$ )which belongs to the Ameki group; hence, water samples from ten (10) wells in areas of high population density namely Okpoko, Fegge, main market, GRA phase 1, Inland town, Nkpor, Obosi, Awada and Mgbemena on 6049'30" $\mathrm{E}$ and 608'830" $\mathrm{N}$ were collected for biological and physiochemical analysis in order to determine its quality for consumption by comparing with established standard of World Health Organization. The samples were analyzed using standard methods. The Coliform counts result showed a range of 1 to 30MPN/100MI while heavy metal value shows that $\mathrm{Fe}>\mathrm{Zn}>\mathrm{Mn}>\mathrm{Ba}>\mathrm{Cu}$. The results for the major cations analyzed shows a mean value of $\mathrm{Na}^{+}$(3.32 $\left.\mathrm{mg} \mathrm{H}^{-1}\right), \mathrm{K}^{+}\left(0.8 \mathrm{mg} \mathrm{l-1}^{-1}\right) \mathrm{Ca}^{2+}$ (8.62 $\left.\mathrm{mg} \mathrm{H}^{-1}\right), \mathrm{Mg}^{2+}\left(2.57 \mathrm{mg} \mathrm{l}^{-1}\right)$, Temperature, pH, Total Dissolved Solid (TDS) and Electrical Conductivity (EC) where measured in situ, major anions where also analyzed and the results shows that the mean value for $\mathrm{HCO}_{3}^{-}\left(61 \mathrm{mg} \mathrm{H}^{-1}\right), \mathrm{PO}_{4}^{3-}\left(61.5 \mathrm{mg} \mathrm{H}^{-1}\right), \mathrm{NO}_{3}^{-}\left(21.6 \mathrm{mg} \mathrm{H}^{-1}\right), \mathrm{SO}_{4^{2-}}\left(99 \mathrm{mgl}^{-1}\right.$ 1), while Cl (450 $\left.\mathrm{mg} \mathrm{H}^{-1}\right)$, Correlation at $P<0.05$ using micro soft excel 2007shows that metals assessed were from similar source. The ultimate result when compared with World Health Organization shows that the groundwater of the middle aquiferous horizon in Onitsha and environ in Eastern Nigeria is polluted in some areas covered in this research and not fit for consumption except when treated appropriately.
\end{abstract}

Keywords. Hydrological, Middle Aquifer, Ameki group, samples and groundwater.

\section{INTRODUCTION}

Some of the major parameters used to assess water quality include heavy metals content, cations, anions, Coliform and E-coli count, TDS, TSS, EC, BOD, COD, pH, etc. When the concentrations of these parameters are high in the body of water above the natural threshold values such that it becomes injurious to man, the water is said to be polluted. In order words, water pollution is said to occur when a body of water is adversely affected due to addition of large amounts of materials to the water, making it unfit for intended use [1]. There are two forms of water pollution; point source and nonpoint source. Point sources of pollution occur when harmful substances are emitted directly into a body of water while nonpoint sources occur indirectly through environmental change. The major sources of environmental pollution include indiscriminate dumping of refuge, activities of mechanic workshop, agricultural practices, effluent discharge, and combustion of fuel, atmospheric metallic burden, and spillage [2, 3].

The study area, Onitsha and environs (Fig. 1) are a notable commercial, ecclesiastical and administrative city which influences its rapid urbanization [4]. The vegetation of the study area is a sub climax of original rainforest, having been virtually cleared due to development. The mean annual temperature is between $22^{\circ} \mathrm{C}$ to $27^{\circ} \mathrm{C}$ and a mean annual rainfall is between $1,500 \mathrm{~mm}$ to $2,500 \mathrm{~mm}$, [4]. Studies have revealed that Onitsha and environs have four aquifers; the shallow, upper, middle and the deep $[4,5]$.The chemistry of the deep aquiferous horizon and water quality assessment have been investigated by early researchers and the results revealed that the water from the deep aquifer is potable when compare to [6]. The findings are attributed to the facts that deep aquifer especially those of confined aquifer can hardly get contaminated hence its portability [5-7]. It is 
imperative to state that aquifer is a hydrological unit formed by alluvial and fluvial deposits and characterize by high permeability, porosity; this characteristics make it vulnerable if not capped by non-permeable material such as clay or deep within the subsurface [24]. Earlier researchers who worked on the soils of Onitsha and environs reported high concentration of the soil parameters which they investigated; the high concentration was attributed to the presence of dumpsite, effluent discharge, industrial and sewage discharge and other anthropogenic activities within the area of study. The leachate from these materials affects the quality of groundwater due to infiltration and percolation [810]. The geology of the study area fall within the Anambra basin in south eastern Nigerian, [21-26]

The present work is to consolidate the existing work and critically examine the chemistry and the water portability of the middle aquiferous horizon, been the most tapped aquifer in the study area; this is important with the view of the fact that water is a universal solvent that we cannot do without in our daily activities. As a result, monitoring and evaluation of water quality is imperative as to safe guide human health and that of aquatic and terrestrial animals who consumed it.

\section{METHODOLOGY}

The study area covers the most densely populated areas of Onitsha and environs which include; Okpoko, Fegge, main market, GRA Phase 1, Inland town, Nkpor, Obosi, Awada and Mgbemena (Fig. 1). Ten (10) water samples from boreholes were collected from the selected areas using Global Positioning System (GPS) to locate the points [8-10]. Well logs from the ten (10) wells were obtained from which a fence diagram (a 3 dimensional diagram) indicating various aquifer and their stratigraphy in three (3) dimension at the surface, [11]. The study areas lie on $6^{0} 49^{\prime} 30^{\prime \prime} \mathrm{E}$ and $6^{0} 8^{\prime} 30^{\prime \prime} \mathrm{N}$.

\section{SAMPLES COLLECTION AND PRESENTATION}

The water samples were collected directly from the boreholes as it was been pumped from the source (aquifer) and were kept in a well labeled $120 \mathrm{ml}$ plastic bottle already rinsed with the water and kept in a cooler with ice cheeps in order to slow down the activities of micro-organism present in it. For the analysis of heavy metals, acidification with $0.5 \mathrm{ml}$ of $\mathrm{HNO}_{3}$ was added to $100 \mathrm{ml}$ of sample in order to keep the required species of the cat ions in solution [23, 25].

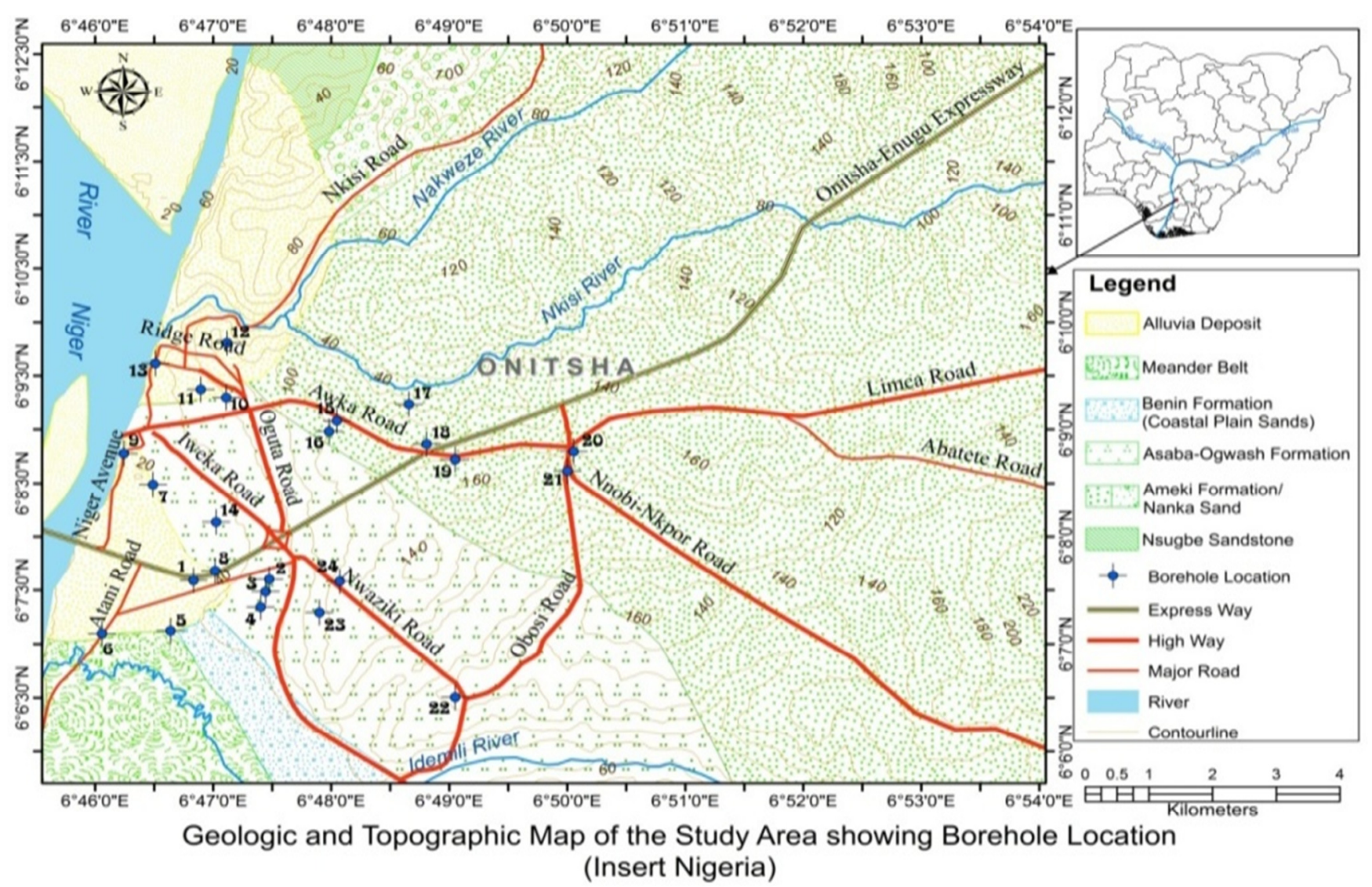

Fig 1: Geologic and Topographic Map of the Study Area 
Table 1: Results of Physiochemical Parameters Analized for in the Study Area

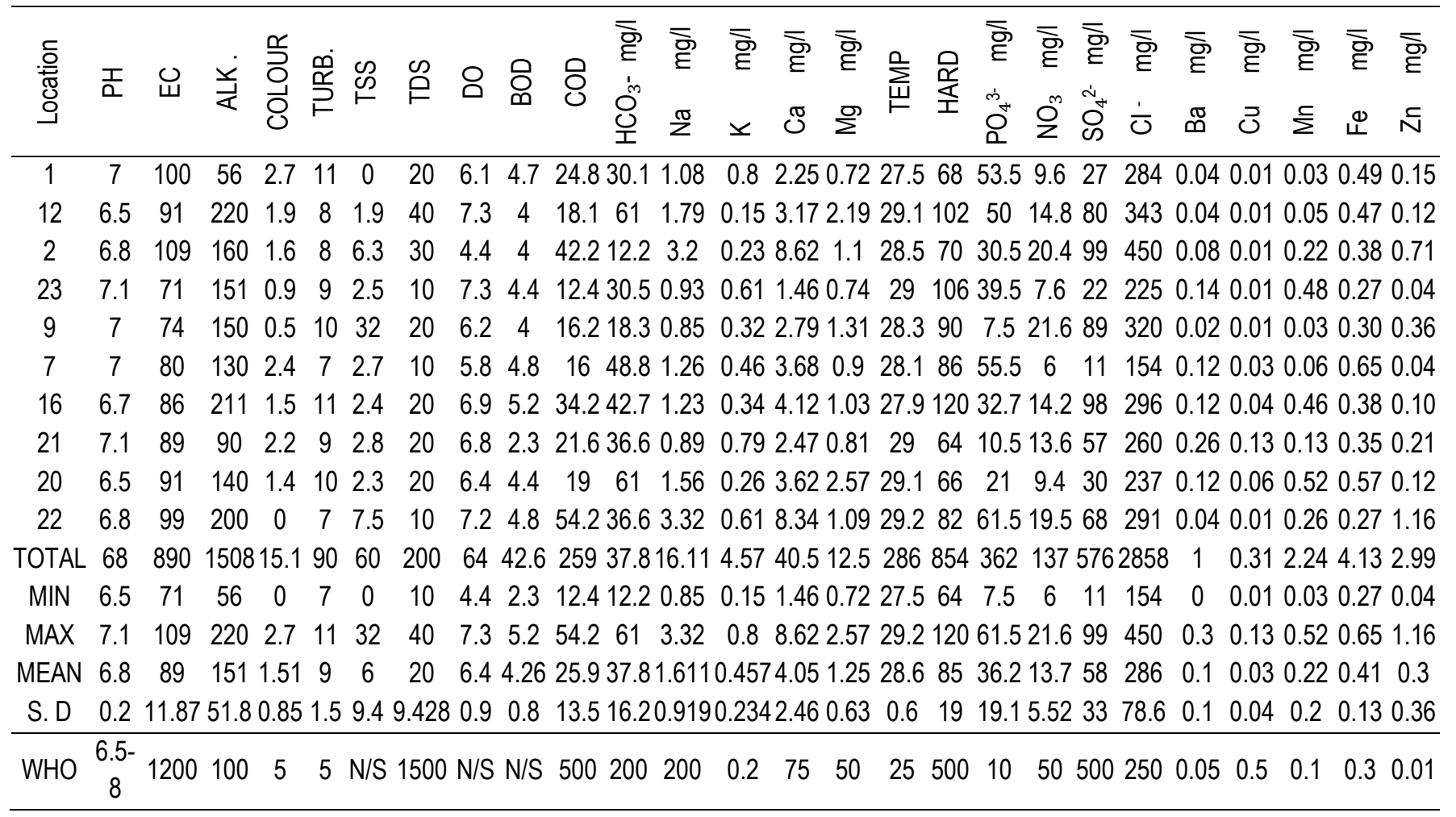

In the same vein, $0.5 \mathrm{ml}$ of concentrated $\mathrm{H}_{2} \mathrm{SO}_{4}$ was added to $100 \mathrm{ml}$ sample to keep the required species of the anion in solution. Since changes occur frequently in water, the samples were immediately taken to the laboratory for analysis, [20]. In some instances where samples were not analyzed immediately, samples were kept at a control temperature of about $4^{\circ} \mathrm{C}$ in a functioning refrigerator.

\section{ANALYTICAL METHODS}

In situ measurements of temperature, $\mathrm{pH}, \mathrm{TDS}$, and $\mathrm{EC}$ were determined intrusively with appropriate probes. The Cat ions $\mathrm{K}^{+}, \mathrm{Ca}^{2+}, \mathrm{Na}^{2+} \mathrm{Mg}^{2+}$ and heavy metals $\mathrm{Zn}$, $\mathrm{Cu}, \mathrm{Fe}, \mathrm{Ba}$ and $\mathrm{Mn}$ were determine using Atomic Absorption Spectrometer (AAS) Model PYE Unicam SP 2900. Other parameters were also determined by standard methods such as American Public Health Association amongst others [12, 13, 20]. Correlation analysis was done using $2007 \mathrm{Ms}$ Excel in order to ascertain the sources of the contaminants.

\section{RESULTS}

Table 1 summarizes all the physiochemical parameters analyzed while (Table 2) show the values of the coli form count. The mean values for the heavy metals were as follows $\mathrm{Zn}\left(0.3 \mathrm{mg} \mathrm{l}^{-1}\right)$, Fe $\left(0.41 \mathrm{mg} \mathrm{l}^{-1}\right)$, Mn (0.22 $\left.\mathrm{mg} \mathrm{l}^{-1}\right), \mathrm{Cu}\left(0.33 \mathrm{mg} \mathrm{l}^{-1}\right)$ and Ba $\left(0.1 \mathrm{mg} \mathrm{l}^{-1}\right)$. The mean values recorded for the anion where as follows; $\mathrm{Cl}^{-}\left(286 \mathrm{mg} \mathrm{l}^{-1}\right), \mathrm{SO}_{4}{ }^{2-}\left(58 \mathrm{mg} \mathrm{l}^{-1}\right), \mathrm{NO}_{3}{ }^{-}(13.7$ $\left.\mathrm{mg} \mathrm{l}^{-1}\right), \mathrm{PO}_{4}^{3-}\left(19.1 \mathrm{mg} \mathrm{l}^{-1}\right)$ and $\mathrm{HCO}_{3}{ }^{-}\left(37.5 \mathrm{mg} \mathrm{l}^{-1}\right)$. The various mean value were record, for the in situ parameters such as $\mathrm{pH}(6.8)$, Temperature $\left(28.6^{\circ} \mathrm{C}\right)$, EC (89), Colour (1.51), Turbidity (9), TSS ( 9.4), TDS ( $20)$; the DO and BOD recorded mean value of $6.4,4.26$ respectively. The coli form count range between 1$30 \mathrm{MPN} / 100 \mathrm{ml}$ as show in (Table 2). It is however important to note that the rate of increase and decrease of the biophysiochemical parameters measured is a function of mobility of the various species in the soil influence by water.

\section{DISCUSSION}

Table 1 shows the summary of the parameters that were measured in the study area. The results show that of all the ten wells study, well $(2,23,7,1621$ and 20) were impacted with Barium, $(1,2,12,2,9,7,16$, 21 and 20) were impacted with Iron, while $(2,23,16$, 21 and 20) were impacted with Manganese. Others include well $(1,12,2,23,9,7,16,21,20$ and 21) impacted with Zinc, and well $(1,12,2,9,16,21$ and 22) recorded Chloride above threshold value. The summary of the areas impacted with the parameters measured is presented in (Table 4) while the location of each well is summarized in (Table 3 ). 
Table 2: Values of Coli Form Count

\begin{tabular}{llc}
\hline S/N & CODE & COLIFORM COUNT \\
\hline 1 & BH1 & 11 \\
2 & BH 12 & 38 \\
3 & BH2 & 23 \\
4 & BH23 & 12 \\
5 & BH9 & 1 \\
6 & BH7 & 12 \\
7 & BH16 & 12 \\
8 & BH21 & 11 \\
9 & BH20 & 13 \\
10 & BH22 & 14 \\
& WHO & 0
\end{tabular}

$\mathrm{BH}=$ Borehole,

WHO $=$ World Health

Organization

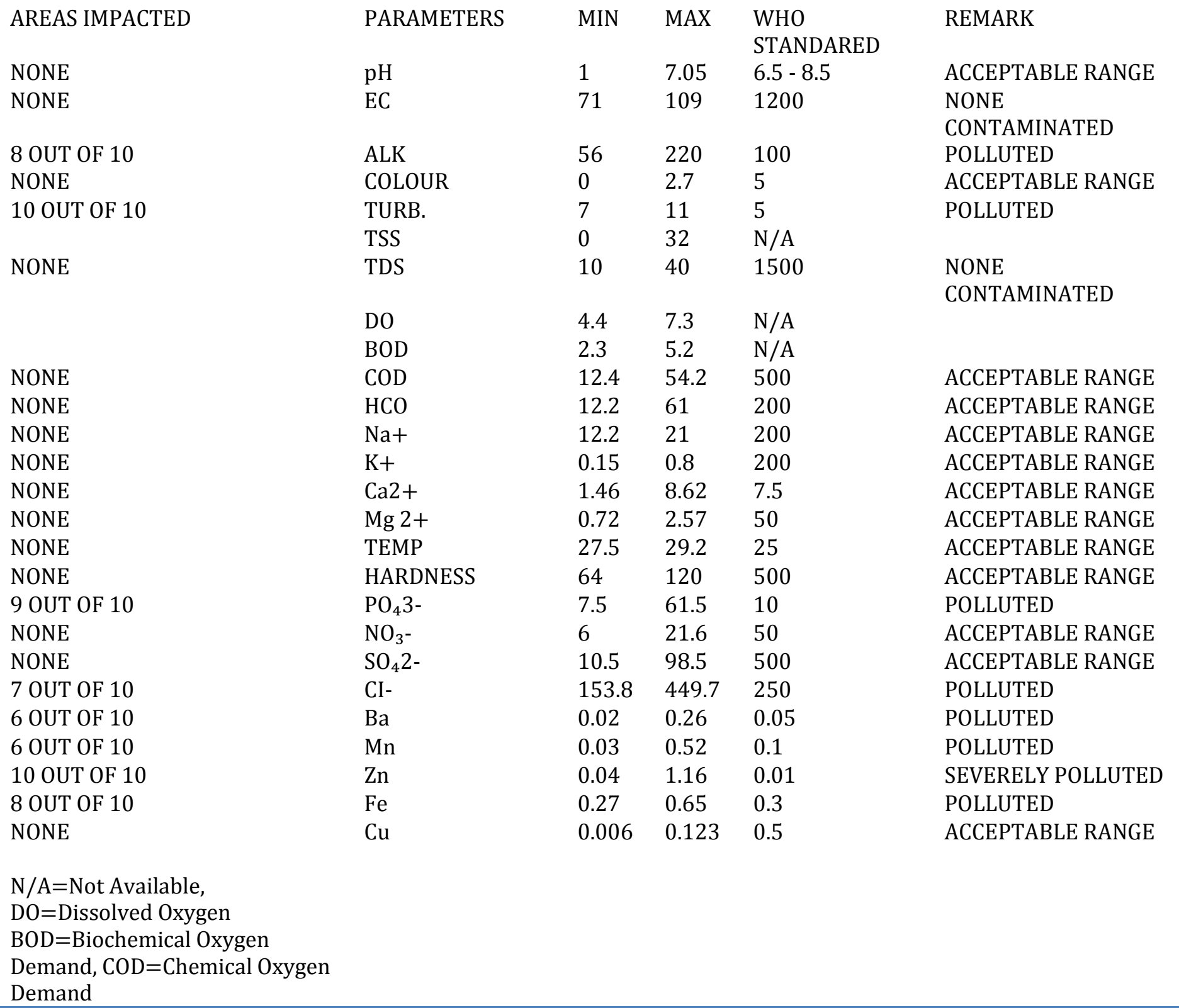




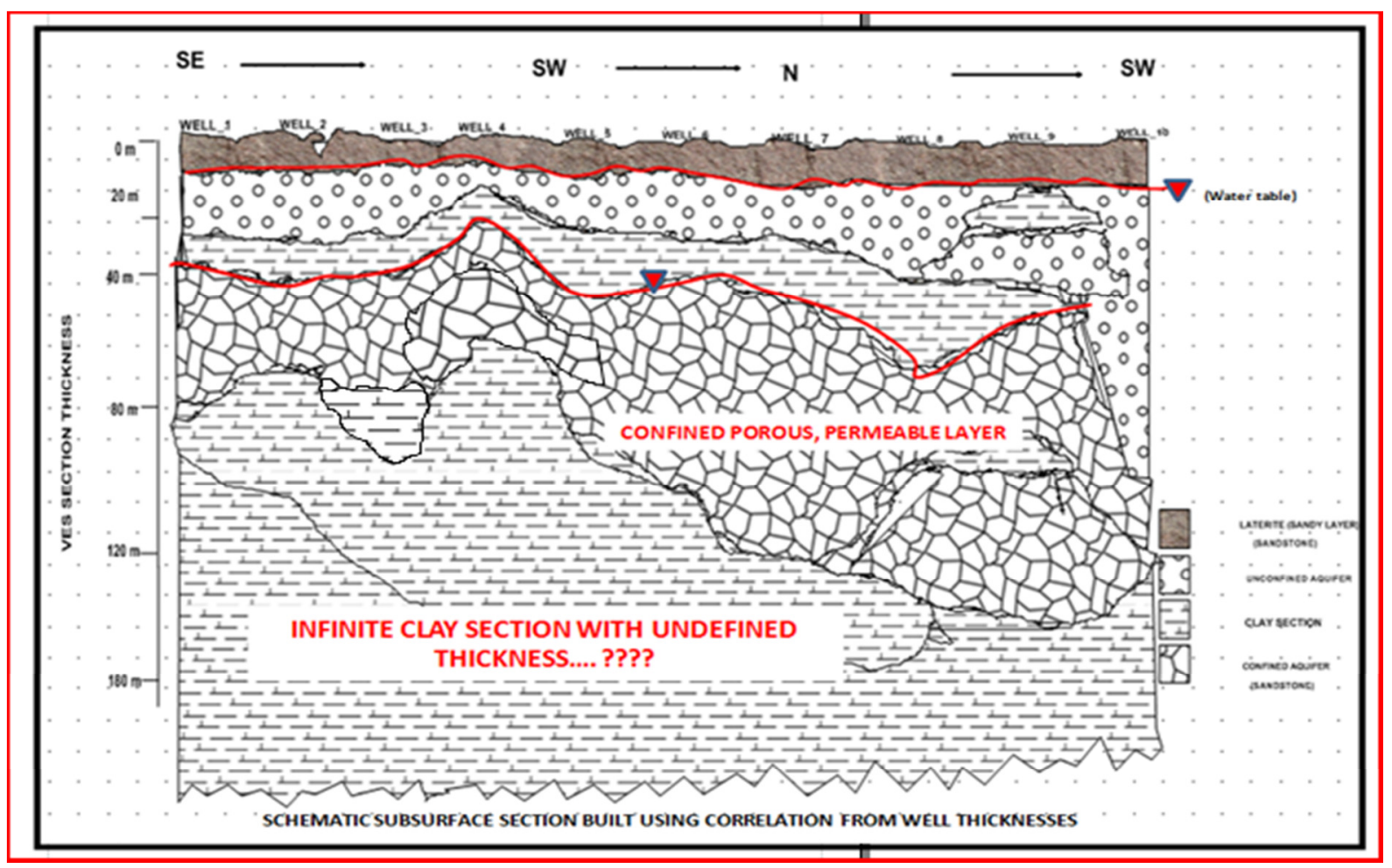

Fig 2: The Sequence Stratigraphy of the Study Area

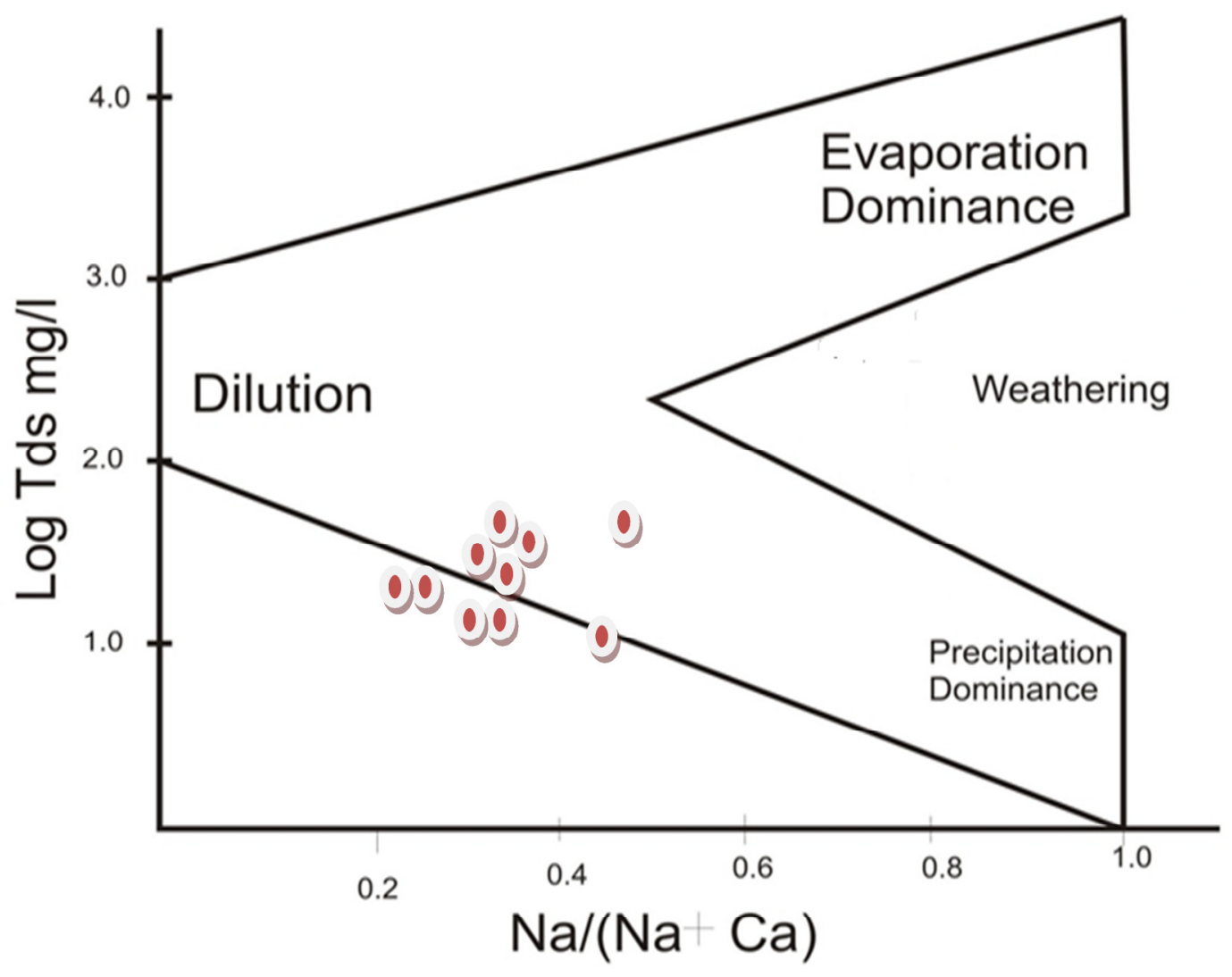

Fig. 3: Gibbs Diagram Showing the Pollution Mode 


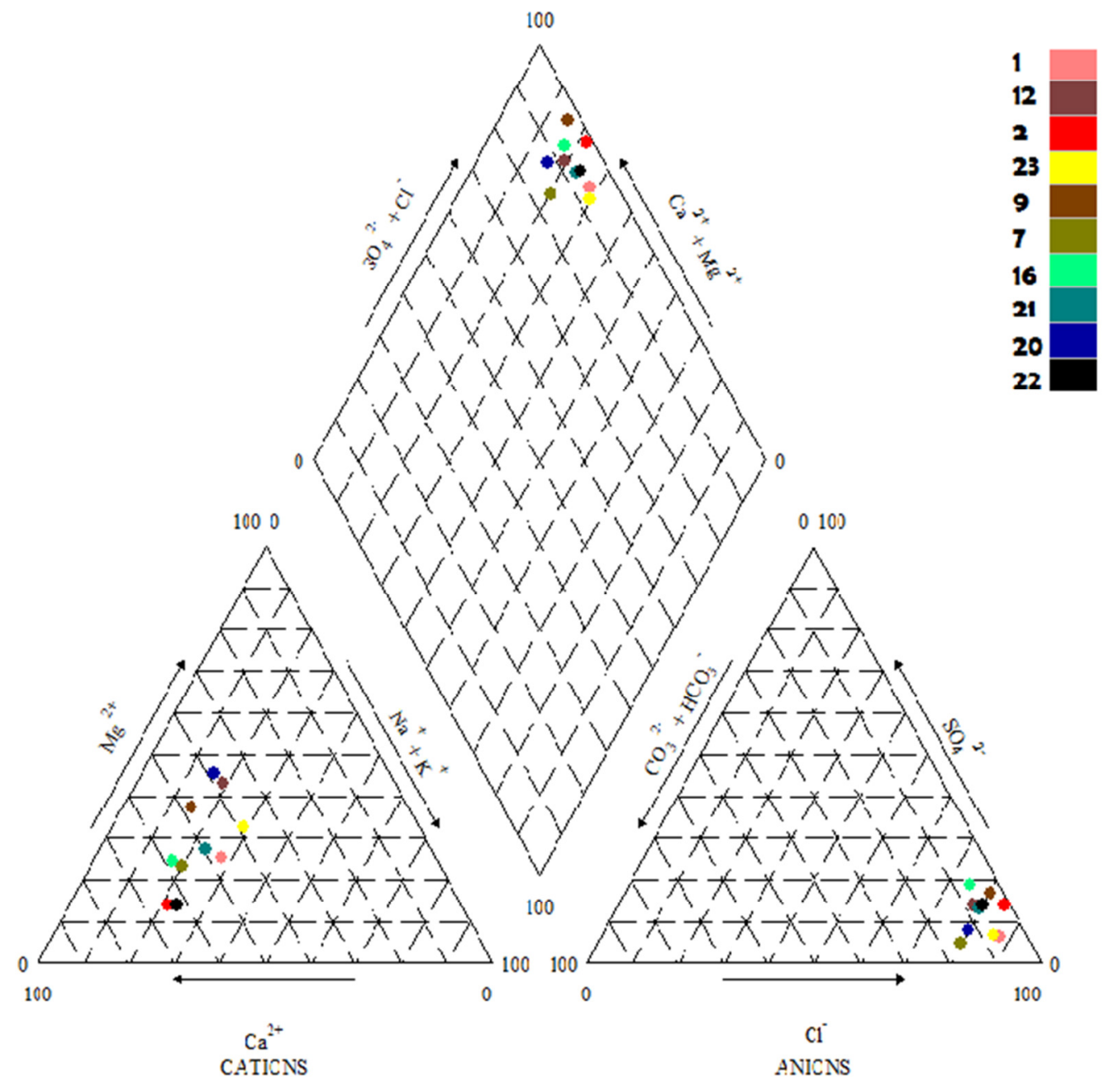

Fig. 4: The Pipers Diagram for the Area of Study

Table 5: Correlation of PH, Cations and Heavy Metals in the Study Area.

\begin{tabular}{|c|c|c|c|c|c|c|c|c|c|c|}
\hline & $\mathrm{PH}$ & $\mathrm{Na}$ & $K$ & $\mathrm{Ca}$ & $M g$ & $\mathrm{Fe}$ & $B a$ & $\mathrm{Cu}$ & $M n$ & $Z n$ \\
\hline $\mathrm{PH}$ & 1 & & & & & & & & & \\
\hline $\mathrm{Na}$ & -0.37576 & 1 & & & & & & & & \\
\hline $\mathrm{K}$ & 0.707924 & -0.27035 & 1 & & & & & & & \\
\hline $\mathrm{Ca}$ & -0.27315 & 0.953277 & -0.27095 & 1 & & & & & & \\
\hline $\mathrm{Mg}$ & -0.85793 & 0.133461 & -0.69934 & 0.017329 & 1 & & & & & \\
\hline $\mathrm{Fe}$ & -0.26597 & -0.16626 & -0.218 & -0.1745 & 0.363093 & 1 & & & & \\
\hline $\mathrm{Ba}$ & 0.256242 & -0.35646 & 0.381157 & -0.28969 & -0.22839 & 0.020005 & 1 & & & \\
\hline $\mathrm{Cu}$ & 0.06257 & -0.33537 & 0.286485 & -0.24798 & 0.01899 & 0.105328 & 0.884152 & 1 & & \\
\hline $\mathrm{Mn}$ & -0.35064 & 0.073862 & -0.14106 & 0.072786 & 0.204482 & -0.16918 & 0.299627 & 0.135762 & 1 & \\
\hline $\mathrm{Zn}$ & -0.03949 & 0.848075 & 0.031569 & 0.859318 & -0.10562 & -0.48857 & -0.34911 & -0.26587 & -0.05435 & 1 \\
\hline
\end{tabular}

Phosphate was impacted in nine (9) wells beside well 9, while sulphate and nitrate were below threshold value for environmental monitoring. None of the study wells was impacted with Colour, Total Dissolved Solid (TDS), Dissolved Oxygen (DO), Biological Oxygen Demand (BOD), Chemical Oxygen Demand (COD), and some major and minor anions, and cat ions. Turbidity of all the wells study were above the required standard by [6] while well 1 and 21 were impacted by alkalinity. The high values of turbidity recorded are traceable to the percolating leachate from the dumpsite, commercial and industrial activities and possibly the underlying bedrock. The heavy metals concentrations were above World Health Organization 
values as shown in (Table 1). The high concentration of chloride and phosphate present is attributed to the flow from septic tanks and sewage sludge [14].The total coli form count range between 1-30MPN/100 ml which is very high against the $0 \mathrm{MPN} / 100 \mathrm{ml}$ requirement by $[6,28]$. The high total coli form count is attributed to the presence of sewage sludge which is as a result of the countless septic tanks present in the study area. This is alarming because the consumers of the water resources derived from the area of study are highly susceptible to health related problems such as cholera and cardiovascular diseases [6, 15].

Concentration of major anions in milli-equivalent per litre were computed and used in plotting trilinear diagram after Piper [16]. Fig 4 in which the milli equivalent per litre was expressed in percentage of cat ions and anions. The graph shows that $\mathrm{Ca}^{2+}$ and $\mathrm{Mg}^{2+}$ are dominant cat ions while $\mathrm{Cl}^{-}$and $\mathrm{SO}_{4}{ }^{2-}$ are the dominant anions. The Gibbs diagram in (Fig. 3) further proof that the occurrence of contaminant in the middle aquiferous horizon was influence by anthropogenic activities particularly the septic tanks, leachate from the major dumpsite couple with the effluent and wastes waters from the various industrial and manufacturing industries within the study area. Furthermore the chemistry of the groundwater generally indicate low dissolve solute and hence low salinity as reflected by the low value of TDS and EC in the range of $10-40 \mathrm{mg} / \mathrm{l}$ and $71-109 \mu \mathrm{s} / \mathrm{m}$ respectively. The low TDS status $(<100 \mathrm{mg} / \mathrm{l})$ permit the classification of groundwater in the study area as freshwater $[17,19]$ while the non-conformity of the heavy metals and microbial population [6] indicate non-suitability for livestock feeding unless treated.

The result of this investigation reveals that the values of TDS, EC and SAR in groundwater within the study area are $<100 \mathrm{mg} / \mathrm{l}, 200 \mu \mathrm{s} / \mathrm{cm}$ and 1.5 respectively. These therefore indicate low salinity sodium (alkali) hazards hence of excellent irrigation qualities [18].

\section{CONCLUSION}

The 3D schematic subsurface section of the well log obtained, using geophysical software revealed that the deep aquiferous horizon is capped with shale and clay materials to the Eastern portion of the study area while to the West, the Shale is thickened (Fig. 2). The shale/clay acts as a protective material to the deep aquifer from being contaminated by filtrating the contaminants from the percolating water hence the portability of the deep aquiferous horizon [5, 27]. It was also observed that there was no clay or shale cap to the middle aquiferous horizon on the eastern domain, this allowed or make possible percolation of contaminants into the aquifer. The strong positive correlation (Table 5) between the cat ions, heavy metals and $\mathrm{pH}$, indicates that the contaminants are from a similar source. A careful look at (Table 1) above, revealed a high concentration of chloride, phosphate and total coli form count; these parameters is attributed to sewage sludge from septic tanks and industrial activities in the study area. It can therefore be concluded that the middle aquifer of the Onitsha and environs are characterized by high concentration of total coli form count, heavy metals ( $\mathrm{Ba}, \mathrm{Fe}, \mathrm{Zn}$, and $\mathrm{Mn})$, anions $\left(\mathrm{PO}_{4}^{3-}\right.$ and $\mathrm{Cl}$ ) alkalinity and turbidity. Other parameters measured in the study area were moderate to low; they include Dissolved Oxygen (DO), $\mathrm{pH}, \mathrm{TDS}, \mathrm{EC}, \mathrm{BOD}, \mathrm{COD}, \mathrm{Temp}, \mathrm{SO}_{4}^{2-}, \mathrm{NO}_{3}{ }^{-}, \mathrm{HCO}_{3}{ }^{-}, \mathrm{Na}^{+}$, $\mathrm{K}^{+}, \mathrm{Mg}^{+}$, Hardness.

Bye and large, the authors predict that if the trend of increasing population and human activities in the study area continued, there will soon be disease epidemics in the nearest geological time frame, therefore all hands must be on deck to profile solutions to the imminent danger.

\section{RECOMMENDATION}

(1) Further studies on speciation on the hydrogeochemical Characteristics should be carried out.

(2) Contractors and drillers are encouraged to drill deeper into the deep aquifer horizon so as to obtain potable water.

(3) Remediation studies on the best treatment option to savage the water problems should be done.

(4) Health studies should be carried out to show the extent of damage on human health (Geomedicine) so that victims will be properly treated.

(5) Further study of the hydrogeology of the study area should be carried out to consolidate of complement existence studies.

\section{REFERENCES}

[1] Maitera, O. N., Bariminas, J. T., Magilli, S. T. "Determination of Heavy metals Level in Water and Sediments of River Gongola in Adamawa state, Nigeria; Journal of an Emerging Trends in Engineering and Applied Sciences 2(5), 2011: 891896

[2] Imasuen, O. I and Omorogieva, O. M. Sources and Environmental Implication of Heavy Metal Pollution in Plants Grown Around Contaminated Site in Edo 
State, Nigeria. Resource Journal in Engineering and Applied Sciences: USA, 2(5) 2013, 385-391.

[3] Asuen, G.O. Ihenye, A.E and Ugboyibo U.J. The Level of Heavy Metal Pollution of Roadside Sediments and Soils in Auchi Municipality, Edo State, Nigeria. Journal of Research in Physical Sciences 1 (1) 2005, pp 28-30

[4] Isikhuemen, M.I The Hydrogeology of Onitsha and Environ. Unpublished M.Sc Thesis, University of Benin, Benin City Nigeria, 2014.

[5] Egboka, B.C.E; Okpoko, E.W Conjunctive uses of Water Resources and Management in Anambra State Nigeria. Journal of Applied Science and Environment management, 10 2008, pp 27-30.

[6] WHO Guideline Values for Chemicals that are of Health Significance in Drinking Water Quality. World Health Organization, Geneva 2006 pp41-49.

[7] Lamb, J.C Water Quality and Its Control. John Wiley and Sons, New York 1985

[8] Nduka, J.K.C., Orisakwe, O.E; Ezenwankwo, L.O., Ezenwa, T.E., Chendo, M.N., Ezeabasili, N.G Acid Rain Phenomenon in Niger Delta Region of Nigeria. Economic, Biodiversity and Public Health Concern. Sci World J. 2008 pp811-818.

[9] Orisakwe, O.E; Asomugha, R; Obi, E; Nduka, J.C; Dioka C.E Impact of Effluents from Cable Manufacturing Plant on Food, Water and Soil Qualities in Nnewi. Pakistan, J.B101. Sci. Vol. 8, 2004 pp. 744-747.

[10] Nwajei, G.E., Iwegbue, M.A.C Heavy Metals in Surface Soils Under Waste Dumps from Onitsha, Nigeria . Bio. SC. J. 2007 7, (2) pp 405-408.

[11] Olabaniyi, S.B; and Efe, S.D Comparative Assessment Rainwater and Groundwater Quality in Oil Producing Area of Nigeria; Environmental and Health Implications. Clattered Institute of Environmental Health, 2007Vol 6, pp. 1-9.

[12] USEPA Drinking Water Treatment Residual Wells. Technical Recommendations 1996

[13] Adelekan, B.A \& Abegunde, K.D Heavy Metals Contamination of Soil and Groundwater at Automobile Mechanic Villages in Ibadan, Nigeria. International Journal of Physical Science 2011 6(5): 1045-1058

[14] Purandara, B.K and Varadarajan, N and Jayashree, K Impact of Sewage on Groundwater Quality, CaseStudy. Pollut. Res, 200322 (2): 189

[15] National Research Council Arsenic in Drinking Water. National Academic Press, Washington DC 1999.
[16] Piper, A.M A graphical Procedure in Geochemical Interpretation of Water Analysis Trans. American Geophysics Union 25, 1944 pp 914-923

[17] Davis, S. N and Deweist, R. J. M, Hydrogeolgy. John Wiley and Sons Inc. 463p

[18] Richer, I.A. (1954): Diagnosis and Improvement of Alkaline Soils. Agric Handbook 60. USDA and IBH Pub. Coy Ltd New Delhi Indian 1966 pp.98-99

[19] Hem, J.D Study and the Interpretation of Chemical Characteristics of Natural Waters. USGS WaterSupply Paper 1970 1473, 2nd Ed.

[20] APHA (America Public Health Association) Standard Methods for the Examination of Water and Waste Water. $18^{\text {th }}$ Edition, Washington D.C. 1985 Pp 4-17

[21] Nfor , B.N Sedimentary Facies and the Diagnostic Characteristics for the Campanian- Eocene Anambra Basin; Unpublished PhD Thesis. Department of Geological Sciences, Nnadi Azikiwe University, Awka 2003 pp236

[22] Rayment, R.A Aspects of the Geology of Nigeria. University Press, Ibadan 1965 133pp

[23] Mendham, J Denney, R.C and Thomas, M.J Vogels Textbook of Quantitative Chemical Analysis. $6^{\text {th }}$ Edition Pearson Education Ltd, Indian, 2002, Pp 197

[24] Amadi, A.N., Nwankwoala, H.O., Olasehinde, P.I., Okoye, N.O., Okunlola, I.A., and Alkali, Y.B Investigation of Aquifer Quality in Bonny Island, Eastern Niger-Delta, Nigeria Using Geophysical and Geochemical Techniques. Journal of Emerging Trends in Engineering and Applied Sciences, 2012, 3 (1): 183-187

[25] APHA Standard Methods for the Examination of Water and Waste Water. (15 ${ }^{\text {th }}$ Edition) Washington D.C American Public Health Association, 1985 pp1134

[26] Isikhueme., M.I and Omorogieva O.M Hydrogeology and Water Quality Assessment of the Middle Aquiferous Horizon of Onitsha and Environs in Anambra Basin, Eastern Nigeria. British Journal of Applied Science and Technology, 20159 (5).

[27] I.M Idehai and O.A Egai Comparative Assessment Of The Geotechnical Properties of Residual Soils In Parts Of Awka And Abuja Areas Of Nigeria. Nigeria Journal of Technology, Vol.33 No 4, 2013, pp 595603

[28] J.I Obianyo A Study of Faecal Coli form Die-Off In Sewage Sludge Drying Bed. Nigeria Journal of Technology, Vol. 34 No. 3 2014, pp.643-649 